\title{
THE USE OF CANE MOLASSES AS PART OF THE CONCENTRATY DAIRY RATION USING MIRRKER GRASS AS ROUGHAGE
}

\author{
By \\ L. Rivera Brenes, ${ }^{1}$ J. I. Cabrera, ${ }^{2}$ and F. J. Marchán. ${ }^{3}$
}

\section{IN'TRODUCTION}

"Only that dairyman can succeed who feeds his cows both economically and efficiently". ${ }^{6}$

Intensive milk production in Puerto Rico is generally dependent upon concentrate feedstuffs. Most of these feedstuffs are imported from the United States at prices which represent more than 50 per cent of the cost of milk production. The total value of dairy feeds imported to the Island during 1945-1946 ${ }^{2}$ was almost four million dollars.

During 1945-1946, Puerto Rico produced around 38.5 million gallons of molasses. Of this, a large amount was used by the rum industry or exported, and very little was used as livestock feed.

In the United States, molasses is added to high-grade mixed feeds on account of its palatability, and also because it is one of the cheapest of readily digestible carbohydrates. ${ }^{14}$ In the past, feeds containing molasses were imported to the Island and dairymen were paying an excessive price for the molasses put into the feed. Due to the fact that in tropical climates molasses undergoes fermentation under prolonged storage, the importation of molasses-containing feeds was discontinued.

As Puerto Rico is a sugar-cane growing country, molasses should be an economical substitute for part of the grain in feeding dairy cows and other livestock on the Island.

\section{LITERATURE REVIEW}

Ellison and Varas Catala, ${ }^{7}$ in Puerto Rico, supplemented the grain ration of one group of cows with cane molasses and of another group with corn chops,* and used cane as the only

* Corn chops-corn and cob chopped.

${ }_{1}$ Associate Animal Husbandman.

2 Assistant Animal Husbandman

${ }^{3}$ Assistant Chemist. 
roughage. The chopped-corn lot consumed more feed and produced more milk, but the greater economy in cost of milk production resulted when the molasses was added to the ration. Labh Singh and Sahi Gambhir ${ }^{12}$ found that for feeding bullocks in India molasses could replace corn pound for pound.

$\mathrm{McC}$ Comas et al. ${ }^{13}$ said that on the basis of average data for four experiments using Herford steers in terms of live-weight produced, the corn-molasses mixture in the ratio of 1 to 1 was approximately 80 per cent as efficient as corn, whereas the mixture in the ratio of 3 to 1 was approximately 90 per cent as efficient. Britnal ${ }^{6}$ feeding dairy cattle in Mississippi, stated that, practically one pound of molasses was equal to one pound of corn. Morrison ${ }^{14}$ cites two Wisconsin experiments where 10 per cent of cane molasses was incorporated into a mixture of palatable concentrates; the milk production was practically the same as on the concentrate mixture without molasses. In these trials, the molasses was worth 89 per cent as much per pound as ground corn.

Bary et al. ${ }^{5}$ found, for fattening steers, that molasses had a calculated value of 85 per cent that of corn. In individual tests, the value ranged from around 85 per cent up to better than 100 per cent of the value of corn. Their experiments indicated that molasses was used most efficiently when fed at around 3 to 4 pounds per head daily.

Experimental studies and practical experience with dairy cattle at the Missouri Station ${ }^{1}$ showed that molasses may satisfactorily replace $1 /{ }_{4}$ to $1 / 3$ of the ground corn. Usually not more than two to three pounds of molasses should be fed daily per 1000 pounds of live weight.

Skinner and King, ${ }^{17}$ feeding cattle in Indiana, came to the conclusion that the advantage of feeding molasses arose from its low cost rather than from the feeding value. The nutritive value of molasses was slightly lower than an equal weight of corn as measured by the rate of gain and finish of the cattle.

Snell et al. ${ }^{18}$ at Louisiana, found that molasses was equivalent to corn grain as a feed for working mules. Their early experiments indicated that molasses is only slightly less valuable than corn pound for pound as a feed for dairy cattle.

It was found in Hawaii, in experiments conducted by Henke ${ }^{10}$ covering a period of seven years, that when properly supplemented with protein-rich feeds, cane molasses could be satisfactorily substituted for one quarter of the concentrate usually 
fed dairy cows. The use of molasses did not affect the reproductive efficiency or increase abortions. Henke emphasizes the importance of using more molasses in the dairy rations due principally to differences in price. Willet et al., ${ }^{19}$ in another series of trials in Hawaii, stated that pigs, from time of weaning until they reach a weight of 60 to 70 pounds, can utilize cane molasses effectively up to levels of 20 per cent of the ration. There was no appreciable difference in the amount of total digestible nutrients required per pound of gain. The data indicate that molasses is equal to barley when fed at these levels and when compared on total-digestible-nutrient basis. The feed cost per pound of gain decreased with the increase in the amount of molasses fed. When molasses was fed at levels of 30 to 40 per cent of the rations, the rate of gain and efficiency in the utilization of feed or the total digestible nutrients decreased markedly. The accompanying diarrhea was another factor that affected the utilization of the high molasses rations.

Ott et al. ${ }^{15}$ used molasses in poultry rations and stated that the use of molasses up to six per cent in the rations substituting corn depends upon the prices of both corn and molasses. Brigs et al. ${ }^{3}$ working with lambs said that the results of a limited amount of work on the tolerance of lambs for blackstrap molasses indicated that lambs can utilize the product at a level of 10 per cent of the ration more efficiently that at a level of $\mathbf{2 5}$ per cent. They ${ }^{4}$ noted that in two digestion trials in which eight lambs were used, substitution of blackstrap molasses for at least one half of the corn in a lamb-fattening ration lowered the coefficient of apparent digestibility for protein, fat and nitrogenfree extract in appreciable amounts. On the other hand, Williams ${ }^{20}$ said that the data of his experiments indicated that the digestibility of the crude fiber, the nitrogen-free extract, and the ether extract was not uniformly affected in either direction by the presence of molasses in the ration. He agrees with Brigs and Heller ${ }^{3}$ in the fact that molasses tends to depress the digestibility of crude protein and dry matter; however, he adds that this depression is so slight that it would scarcely be appreciable in ordinary feeding practices.

Kraus ${ }^{11}$ at Ohio, found that cane molasses as a supplement to milk for rats produced excellent growth, prevented nutritional anemia, and was of value for haemoglobin regeneration in anemia. Beet molasses did not prevent anemia and had no beneficial effects on rats suffering from nutritional anemia. Chemical 
analyses showed that cane molasses contained larger quantities of iron and copper than did beet molasses.

Molasses seems, therefore, to have a well-defined position as a feed for livestock. Its value has been compared with corn in many different experiments. In conclusion, it can be said that its value ranges from 80 to 100 per cent of the value of corn or other carbohydrate feed and the variation depends on the proportion which is used in the mixture. For dairy cows care should be taken to maintain the protein content of the mixture at an adequate level to prevent harmful effects on milk production.

\section{EXPERIMENTAL}

Eighteen cows divided in three groups of six each were used in the experiment. The groups were balanced according to the stage of lactation period and milk production. All the cows were giving over eight.pounds of milk daily and none was over ten months in lactation. Except for four purebred Holstein cows, all cows were Holstein-Native crossbreds with varying amounts of Holstein blood.

The experiment consisted of a single reversal trial using the groups as follows: After a five day pre-feeding period, the first group was fed regular Merker grass and regular 20 per cent protein concentrate ration at a level of 1 pound of concentrate for every 2.0 pounds of milk. A narrow ratio of feed to milk was used to compensate for the lower quality of the roughage. The second group was fed the same kind of grass but the concentrate ration consisted of four parts of regular 20 per cent protein concentrate feed and one part of cane molasses. The third group was fed young Merker grass plus the molassesconcentrate ration. The first part of the experiment lasted for 18 days, pre-feeding excluded.

For the second part of the experiment, the first two groups were switched on the concentrate rations. The third was fed the regular mature Merker grass pus the molasses-concentrate ration. The second part of the experiment lasted for 17 days, pre-feeding excluded.

The cows were weighed for three consecutive days at the beginning of the experiment, at the end of the first part and at the end of the second part of the experiment. Roughage consumption and milk records were kept daily for each individual cow. Forage samples for moisture content were gathered twice a week. These samples were dried in an oven at $70^{\circ} \mathrm{C}$. 
The molasses was mixed with the feed by spreading the feed on a concrete floor and sprinking the molasses over it as evenly as possible. Two men with shovels mixed the concentrate feed and molasses thoroughly. The mixing was done this way due to the fact that the majority of the dairies in the Island do not have mixers to mix the ingredients. Enough feed was mixed every time for two or three days.

The milk production of the animals in the different groups depended on a number of factors, among which the ration fed, the stage of lactation, and individual differences between the animals may be mentioned. In order to determine the effects of the differences in the rations fed on the milk production of the different groups, a regression equation was adapted to the milk production figures. The equation constants represent the differences in milk production due to differences between the rations fed and to the effect of the stage of lactation.

Fitting of the regression equation and calculation of the standard error of the constants were made according to the methods described by Snedecor. ${ }^{16}$ Difference in roughage consumption as well as weight differences were also studied. 


\section{RESULTS}

Milk production for the experimental periods is presented in table 1. Pre-feeding periods were excluded.

TABLE NO. 1

MILK PRODUCTION IN POUNDS FOR ALL ANIMALS DURING THE EXPERIMENTAL PERIODS*

\begin{tabular}{|c|c|c|c|}
\hline Name of Cow & $\begin{array}{l}\text { Ration } \\
\text { No. } 1\end{array}$ & $\begin{array}{l}\text { Ration } \\
\text { No. } 2\end{array}$ & $\begin{array}{l}\text { Ration } \\
\text { No. } 3\end{array}$ \\
\hline & $\begin{array}{l}\text { Second } \\
\text { Period }\end{array}$ & $\begin{array}{c}\text { First } \\
\text { Period }\end{array}$ & \\
\hline 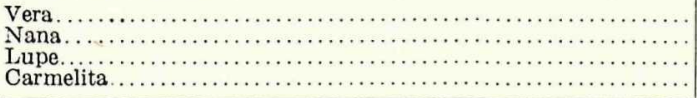 & $\begin{array}{r}149.2 \\
93.6 \\
368.2 \\
321.1\end{array}$ & $\begin{array}{l}176.9 \\
151.2 \\
395.9 \\
325.8\end{array}$ & $\begin{array}{l}\cdots \cdots \cdots \\
\ldots \ldots \ldots \cdots \\
\ldots \ldots \cdots \cdots \\
\cdots \cdots \cdots\end{array}$ \\
\hline & $\begin{array}{c}\text { First } \\
\text { Period }\end{array}$ & $\begin{array}{l}\text { Second } \\
\text { Period }\end{array}$ & \\
\hline 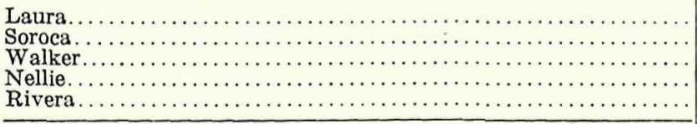 & $\begin{array}{l}184.7 \\
502.0 \\
257.0 \\
322.2 \\
376.6 \\
\end{array}$ & $\begin{array}{l}192.8 \\
493.0 \\
158.3 \\
285.9 \\
366.9 \\
\end{array}$ & 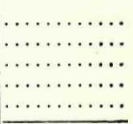 \\
\hline . & & $\begin{array}{l}\text { Second } \\
\text { Period }\end{array}$ & $\begin{array}{c}\text { First } \\
\text { Period }\end{array}$ \\
\hline 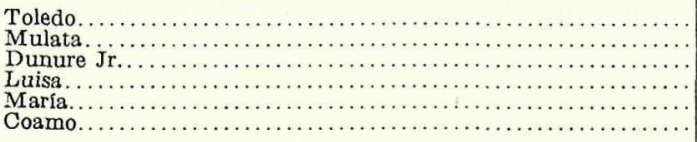 & 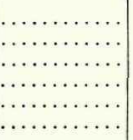 & $\begin{array}{r}164.0 \\
82.2 \\
264.4 \\
283.8 \\
286.9 \\
214.3\end{array}$ & $\begin{array}{l}192.7 \\
121.8 \\
305.0 \\
362.3 \\
343.1 \\
372.6\end{array}$ \\
\hline
\end{tabular}

* Three cows were not able to finish in the experiment due to sickness; they were not included in the comparisons.

Ration No. 1-cows on regular Merker grass and concentrate alone.

Ration No. 2-cows on regular Merker grass and molasses-concentrate.

Ration No. 3-cows on young Merker grass and molasses-concentrate.

The constants of the fitted equation and their respective standard errors are as follows:

\begin{tabular}{cccl} 
& Constants & S. E. & \multicolumn{1}{c}{ Meaning of Constants } \\
A & 7.65 & 15.38 & Difference in production due to rations 2-1 \\
B & -36.26 & 24.31 & Difference in production due to rations 1-3 \\
C & 32.27 & 15.38 & Difference in production due to periods 1-2
\end{tabular}

The above constants are subject to twelve degrees of freedom and none of them is, therefore, significant. Thus, the evidence available does not indicate any superiority of the 100 per cent concentrate feed as against 80 per cent concentrate feed and 20 per cent molasses or vice versa.

Molasses did not have any significant depressive effect on milk production when used as a substitute of the concentrate ration to the extent of 20 per cent. On the other hand the molasses has definite advantages that will be discussed later on. 
TABLE NO. 2

SUMMARY OF ROUGHAGE CONSUMPTION BY GROUPS

\begin{tabular}{|c|c|c|c|c|c|c|c|c|c|c|}
\hline No. of cows & $\begin{array}{l}\text { Ave. wgt. } \\
\text { pounds }\end{array}$ & $\begin{array}{c}\text { A verage } \\
\text { pounds } \\
\text { consumed }\end{array}$ & $\begin{array}{c}\text { A verage } \\
\text { per cent } \\
\text { dry matter }\end{array}$ & $\begin{array}{l}\text { A verage } \\
\text { D. M. } \\
\text { consumed } \\
\text { daily }\end{array}$ & $\begin{array}{l}\text { D. M. } \\
\text { per }^{2} 100 \\
\text { pounds } \\
\text { L. W. }\end{array}$ & $\begin{array}{l}\text { Ave. wgt. } \\
\text { pounds }\end{array}$ & $\begin{array}{l}\text { Average } \\
\text { pounds } \\
\text { consumed }\end{array}$ & $\begin{array}{c}\text { A verage } \\
\text { per cent } \\
\text { dry matter }\end{array}$ & $\begin{array}{l}\text { Average } \\
\text { D. M. } \\
\text { consumed } \\
\text { daily }\end{array}$ & $\begin{array}{l}\text { D. M. } \\
\text { per } 100 \\
\text { pounds } \\
\text { L. W. }\end{array}$ \\
\hline & \multicolumn{5}{|c|}{$\begin{array}{c}\text { First Period } \\
\text { Regular Merker grass molasses-concentrate }\end{array}$} & \multicolumn{5}{|c|}{$\begin{array}{l}\text { Second Period } \\
\text { Regular Merker grass no-molasses concentrate }\end{array}$} \\
\hline \multirow[t]{2}{*}{$4, \ldots \ldots \ldots, \ldots, \ldots, \ldots, \ldots, \ldots, \ldots, \ldots$} & 941 & $1,276.00$ & 28.00 & 20.00 & 2.13 & 917 & $1,299.00$ & 28.00 & 21.00 & 2.36 \\
\hline & \multicolumn{5}{|c|}{ Regular Merker grass no molasses concentrate } & \multicolumn{5}{|c|}{ Regular Merker grass molasses concentrate } \\
\hline \multirow[t]{2}{*}{5} & 1,033 & $1,171.00$ & 2800 & 18.00 & 1.78 & 1,012 & $1,280.00$ & 28.00 & 21.00 & 2.11 \\
\hline & \multicolumn{5}{|c|}{ Young Merker grass molasses concentrate } & \multicolumn{5}{|c|}{ Regular Merker grass no molasses concentrate } \\
\hline $6 . .$. & 891 & $1,445.00$ & 25.00 & 20.00 & 2.26 & 878 & $1,203.00$ & 28.00 & 20.00 & 2.28 \\
\hline
\end{tabular}

1 D. M. dry matter.

In checking, results may not agree with data due to the fact that figures were rounded in the table. 
Although this was a short time experiment, the results were similar to those obtained by Henke ${ }^{10}$ in Hawaii, in a seven-year period, and by other workers.

The average amount of roughage consumed during the experimental periods by each group of cows is presented in table 2.

Except in the case of the second group in the first experimental period, the average dry matter consumed per 100 pounds of live weight during the course of the experiment showed very little difference, indicating a more or less equal intake of nutrients from the roughage. When the data were treated statistically, they showed no significant differences among the groups.

Variations in bodily weight during the experiment are shown in table 3.

WEIGHT LOSSES DURING THE COURSE OF THE EXPERIMENT

\begin{tabular}{|c|c|c|c|}
\hline Group No. & $\begin{array}{l}\text { No. of } \\
\text { cows }\end{array}$ & $\begin{array}{l}\text { A verage } \\
\text { loss } \\
\text { in weight } \\
\text { by groups, } \\
\text { in pounds }\end{array}$ & $\begin{array}{l}\text { A verage } \\
\text { loss } \\
\text { per cows } \\
\text { in pounds }\end{array}$ \\
\hline 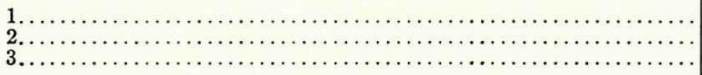 & $\begin{array}{l}4 \\
5 \\
6\end{array}$ & $\begin{array}{r}98.00 \\
105.00 \\
52.00\end{array}$ & $\begin{array}{r}24.50 \\
21.00 \\
8.60\end{array}$ \\
\hline
\end{tabular}

As shown by the average weight lost per cow in the 44 days of experiment (pre-feeding periods included) they practically maintained their initial weights throughout. No statistically significant difference was found among the groups. 


\section{DISCUSSION}

Molasses has been always the cheapest source of carbohydrate food in Puerto Rico. An illustration of this is presented in table 4 , where prices for an eleven-year period are compared.

TABLE No. 4

RE'TAIL PRICES FOR MOLASSES AND 20 PER CENT PROTEIN DAIRY FEED 1938 TO 1948

\begin{tabular}{|c|c|c|c|}
\hline Year & $\begin{array}{l}\text { Molasses } \\
\text { Drums of } \\
54 \text { gallons, } \\
650 \text { lbs. }\end{array}$ & $\begin{array}{c}\text { Price of } \\
\text { molasses, } \\
\text { per } 100 \\
\text { pounds }\end{array}$ & $\begin{array}{l}\text { Price of } \\
20 \% \text { protein }{ }^{2} \\
\text { dairy } \\
\text { feed, } \\
\text { per } 100 \\
\text { pounds }\end{array}$ \\
\hline 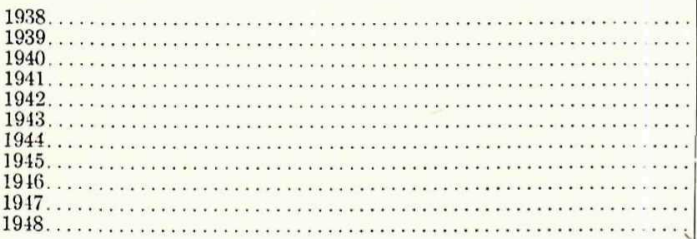 & $\begin{array}{r}\$ 1.62 \\
1.62 \\
2.70 \\
2.70 \\
5.13 \\
2.50 \\
6.48 \\
7.34 \\
7.34 \\
8.37 \\
12.04\end{array}$ & $\begin{array}{r}\$ 0.25 \\
0.25 \\
0.42 \\
0.42 \\
0.79 \\
0.38 \\
1.00 \\
1.13 \\
1.13 \\
1.29 \\
1.85\end{array}$ & $\begin{array}{l}\$ 1.98 \\
2.10 \\
2.24 \\
2.43 \\
3.61 \\
3.48 \\
3.79 \\
3.64 \\
4.29 \\
4.81 \\
5.45\end{array}$ \\
\hline
\end{tabular}

1 Personal, communication of the Administrator, Central San José, Río Piedras, July 1948.

2 Personal communication of the Manager. Sociedad Agrícola Cooserativa. San Juan, Puerto Rico, July 1948 .

A real saving will be attained due to the difference in prices, plus other advantages such as those of adding palatability and flavor to the ration. A simple way of calculating the saving by the use of molasses as 20 per cent of the concentrate ration is as follows.

Actual cost of 100 pounds of 20 per cent total protein dairy feed-_--- $\$ 5.50$

Actual cost of 100 pounds of molasses____- \$1.85

Cost of 80 pounds of 20 per cent dairy feed__________ $\$ 4.40$

Cost of 20 pounds of molasses.

Cost of one hundred pounds of the mixture

In the above example there will be a saving of 73 cents or 13 per cent of the cost of the feed, due to the use of molasses. The net income will be a little less due to the labor used in the preparation of the mixture. Using 1945-46 figures, which show that the Island imported around four million dollars of concentrate feeds, the savings will amount to one-half million dollars.

At this point of the discussion two questions arise. Does the addition of that amount of molasses appreciably affect the percentage of total protein in the mixture?, and, do the cows get adequate amounts of protein from that mixture for normal milk production? Using molasses at a rate of 20 per cent of the 
concentrate feed the percentage of protein in a 20 per cent protein concentrate mixture is lowered, theoretically, to 16 per cent. The results of the experiment indicated that the milk production was normal.

Extensive work conducted at the New York (Cornell) Station ${ }^{8}$ has shown that very little difference in milk production is to be expected when feeding concentrates containing 16 per cent and 20 per cent protein at the conventional ratio of one pound of feed to three and one half pounds of milk, using Timothy-clover mixed hay and corn silage. Further studies at Ithaca $^{9}$ indicated that a very small increase in milk production could be expected from a 20 per cent total protein concentrate as compared to the 16 per cent total protein concentrate, but this increase in production is not large enough to warrant the purchase of a 20 per cent total protein over a 16 per cent if the cost of the 20 per cent is greater.

Experiments conducted at this Station (J. I. Cabrera, unpublished results) showed no significant difference in production when a 16 per cent total protein mixture was compared to a 20 per cent, using ratios of one pound of feed to two pounds of milk or a ratio of one to three respectively. In a second experiment, 20 and 24 per cent total protein mixtures were better than the 16 per cent. Henke ${ }^{10}$ stated that using protein-rich feeds, molasses can be substituted for 25 per cent of the mixture.

These results show that dairymen in Puerto Rico and farmers in general should be using molasses on a larger scale as feed for livestock. Its nutritive value has been known for years, (see literature review). The Island produces a large amount of it most of which is sold abroad, due to a lack of acceptable prices in the local market. If the usage of molasses becomes general throughout the Island, both cane-growers and dairymen will benefit.

\section{SUMMARY AND CONCLUSIONS}

Two groups of cows were fed regular Merker grass soilage, 20 per cent protein concentrate, and a mixture of four parts of a 20 per cent protein concentrate plus one part molasses in a switch-back feeding trial. A third group was fed young Merker grass for the first part of the experiment, and regular Merker grass for the second part, plus the molasses-concentrate ration with each grass. 
Statistical analysis of the data indicates that molasses did not have any depressive effect on milk production. The amount of dry matter in roughage consumed per 100 pounds of live weight was essentially the same for all groups; the difference was statistically non-significant. Although body weight was not maintained throughout the experiment, the difference in weight lost among groups was not statistically significant.

Due to the difference in price between molasses and the mixed dairy feeds, the use of molasses can effect considerable saving to the farmer who uses it as part of the concentrate ration. It can be substituted for 20 per cent of the concentrate ration and probably more.

As Puerto Rico is a sugar cane producing area, molasses should be used locally to a greater extent as a livestock feed. It is readily available and is the cheapest source of carbohydrates on the Island.

\section{ACKNOWLEDGMENT}

The authors are greatly indebted to Dr. W. W. Green for his invaluable suggestions and to Dr. B. Capó for his assistance in the calculation of the statistics and the revision of the manuscript.

\section{REFERENCES}

1. Anonymous. Cane molasses (blackstrap) as livestock feed. Department of Animal Fiusbandry, Dairy Husbandry and Poultry Husbandry. Mo. Agr. Expt. Sta. Cir. 184:1-4, 1935.

2. Annual Book of Statisties of Puerto Rico. Department of Agriculture and Commerce, Bureau of Commeree, pp. 92, 194.5-46.

3. Briggs, H. IM. and Heller, V. G. Effect of adding blackstrap molasses, potassium salts, sucrose, and corn syrop to a lamb fattening ration. Jour. Agr. Res. 67:359-67, Nov. 1943.

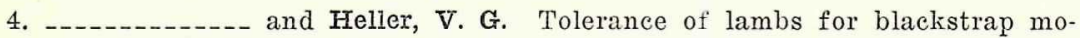
lasses. Jour. Agr. Res. 71:81- 7 , July 1945.

5. Bray, C. I., Snell, M. G., Morrison, F. I., and Jackson, M. E. Feeding blackstrap molasses to fattening steers. La. Agr. Expt. Sta. Bulletin $394: 1-43,1945$.

6. Britnal, E. Blackstrap molasses for dairy cattle. Miss. Agr. Expt. Sta. Cir. 384 pp., 1921.

7. Ellison, W. M. and Varas Cátala, J. Corn chops vs. cane molasses for milk production in Puerto Rico. Puerto Rico Department of Agriculture and Labor, Ann. Rept. Agr. Expt. Sta., pp. 99-100, 1927-28.

8. Harrison, E. S. and Savage, E. S. The effect of different plans of protein intake upon milk production. Cornell Univ. Agr. Expt. Sta., Bulletin 540, 1932. 
9. plans of protein intake upon milk production. II-Further comparison of 16-20 and 24 per cent mixtures. Cornell Univ. Agr. Expt. Sta. Bulletin 578, 1933.

10. Henke, L. A. Cane molasses as a feed for dairy cows. Hawaii Agr. Expt. Sta. Bulletin 73:1-17, 1934.

11. Kraus, W. E. Antianemic potency of cane molasses and beet molasses. Ohio Agr. Expt. Sta. Bimonthly Bulletin, 1947:182-3, 1930.

12. Labh Singh, and Sadhi Gonabhir Singh. Factory cane molasses as a cattle feed. Agr. and Livestock in India, 7:347-58, May, 1937.

13. McComas, E. W., Douglas, J. B., and Southwell, B. L. Corn-molasses mixture compared with corn for fattening beef cattle in a coastal plain area. U.S. Agr. Tech. Bulletin 864:1-10, 1943.

14. Morrison, F. B. Feeds and feeding. 20th ed. pp. 398 and 528, 1942. The Morrison Publishing Co. Ithaca, New York.

15. Ott, W. H., Baucker, R. V., and Knondil, H. C. Feed cane molasses as a constituent of poultry rations; molasses for adult chickens. Poultry Sci. 21:536-9, 1942.

16. Snedecor, George W. Statistical methods. The Iowa State College Press pp. 169 and 214, 1946.

17. Skinner, J. H. and King, F. G. Cattle feeding. 1936-1937. Cane molasses. Indiana Agr. Expt. Sta. Bulletin 430:1-8, 1938.

18. Snell, M. G., Upp, C. W., and Lush, R. H. Blackstrap molasses as a livestock feed. La. Agr. Expt. Sta. Circ. 19:1-4, 1937.

19. Willet, E. I., Work, S. H., Henke, L. A., and Maruyama, C. Cane molasses for pigs from weaning to a weight of seventy pounds. Hawaii Agr. Expt. Sta. Tech. Bulletin 3:1-15, 1946.

20. Williams, P. S. Effect of cane molasses on the digestibility of a complete ration fed to dairy cows. Bibliog. Jour. of Dairy Sci. 8:94-104, March 1925. 